OPEN ACCESS

Edited by:

Christian Grenz,

UMR7294 Institut Méditerranéen

d'Océanographie (MIO), France

Reviewed by:

Michael Joseph Durako,

University of North Carolina

Wilmington, United States

Bruno Lansard,

Université de Versailles

Saint-Quentin-en-Yvelines, France

*Correspondence:

Kasper Elgetti Brodersen kasper.elgetti.brodersen@bio.ku.dk

Peter I. Macreadie

p.macreadie@deakin.edu.au

tThese authors have contributed equally to this work and share first-authorship

Specialty section:

This article was submitted to Marine Ecosystem Ecology,

a section of the journal

Frontiers in Marine Science

Received: 01 November 2018

Accepted: 14 January 2019

Published: 01 February 2019

Citation:

Brodersen KE

Trevathan-Tackett SM, Nielsen DA, Connolly RM, Lovelock CE

Atwood TB and Macreadie PI (2019)

Oxygen Consumption and Sulfate

Reduction in Vegetated Coastal

Habitats: Effects of Physical

Disturbance. Front. Mar. Sci. 6:14.

doi: 10.3389/fmars.2019.00014

\section{Oxygen Consumption and Sulfate Reduction in Vegetated Coastal Habitats: Effects of Physical Disturbance}

\author{
Kasper Elgetti Brodersen ${ }^{1,2 *}$, Stacey M. Trevathan-Tackett ${ }^{1,3+}$, Daniel A. Nielsen ${ }^{1}$, \\ Rod M. Connolly, Catherine E. Lovelock ${ }^{5,6}$, Trisha B. Atwood ${ }^{6,7}$ and \\ Peter I. Macreadie ${ }^{1,3 *}$
}

\begin{abstract}
${ }^{1}$ Climate Change Cluster, School of Life Sciences, University of Technology Sydney, Sydney, NSW, Australia, ${ }^{2}$ Marine Biological Section, Department of Biology, University of Copenhagen, Helsingør, Denmark, ${ }^{3}$ Centre for Integrative Ecology, School of Life and Environmental Sciences, Deakin University, Geelong, VIC, Australia, ${ }^{4}$ Australian Rivers Institute - Coast and Estuaries, School of Environment and Science, Griffith University, Gold Coast, QLD, Australia, ${ }^{5}$ School of Biological Sciences, The University of Queensland, St Lucia, QLD, Australia, ${ }^{6} \mathrm{Global}$ Change Institute, The University of Queensland, St Lucia, QLD, Australia, ${ }^{7}$ Department of Watershed Sciences and The Ecology Center, Utah State University, Logan, UT, United States
\end{abstract}

Vegetated coastal habitats (VCHs), such as mangrove forests, salt marshes and seagrass meadows, have the ability to capture and store carbon in the sediment for millennia, and thus have high potential for mitigating global carbon emissions. Carbon sequestration and storage is inherently linked to the geochemical conditions created by a variety of microbial metabolisms, where physical disturbance of sediments may expose previously anoxic sediment layers to oxygen $\left(\mathrm{O}_{2}\right)$, which could turn them into carbon sources instead of carbon sinks. Here, we used $\mathrm{O}_{2}$, hydrogen sulfide $\left(\mathrm{H}_{2} \mathrm{~S}\right)$ and $\mathrm{pH}$ microsensors to determine how biogeochemical conditions, and thus aerobic and anaerobic metabolic pathways, vary across mangrove, salt marsh and seagrass sediments (case study from the Sydney area, Australia). We measured the biogeochemical conditions in the top $2.5 \mathrm{~cm}$ of surface $(0-10 \mathrm{~cm}$ depth) and experimentally exposed deep sediments (>50 cm depth) to simulate undisturbed and physically exposed sediments, respectively, and how these conditions may affect carbon cycling processes. Mangrove surface sediment exhibited the highest rates of $\mathrm{O}_{2}$ consumption and sulfate $\left(\mathrm{SO}_{4}{ }^{2-}\right)$ reduction based on detailed microsensor measurements, with a diffusive $\mathrm{O}_{2}$ uptake rate of $102 \mathrm{mmol} \mathrm{O}_{2} \mathrm{~m}^{-2} \mathrm{~d}^{-1}$ and estimated sulfate reduction rate of $57 \mathrm{mmol} \mathrm{S}_{\text {tot }}{ }^{2-} \mathrm{m}^{-2} \mathrm{~d}^{-1}$. Surface sediments $(0-10 \mathrm{~cm})$ across all the VCHs generally had higher $\mathrm{O}_{2}$ consumption and estimated sulfate reduction rates than deeper layers (>50 cm depth). $\mathrm{O}_{2}$ penetration was $<4 \mathrm{~mm}$ for most sediments and only down to $\sim 1 \mathrm{~mm}$ depth in mangrove surface sediments, which correlated with a significantly higher percent organic carbon content $\left(\% \mathrm{C}_{\text {org }}\right)$ within sediments originating from mangrove forests as compared to those from seagrass and salt marsh ecosystems. Additionally, $\mathrm{pH}$ dropped from 8.2 at the sediment/water interface to $<7-7.5$ within the first $20 \mathrm{~mm}$ of sediment within all ecosystems. Prevailing 
anoxic conditions, especially in mangrove and seagrass sediments, as well as sediment acidification with depth, likely decreased microbial remineralisation rates of sedimentary carbon. However, physical disturbance of sediments and thereby exposure of deeper sediments to $\mathrm{O}_{2}$ seemed to stimulate aerobic metabolism in the exposed surface layers, likely reducing carbon stocks in VCHs.

Keywords: biogeochemistry, blue carbon, flux, mangrove, tidal salt marsh, seagrass, sediment

\section{INTRODUCTION}

Vegetated coastal habitats (VCHs) such as seagrass meadows, salt marshes and mangrove forests are increasingly recognized as high-value ecosystems (Costanza et al., 1997; Harborne et al., 2006; Barbier et al., 2011) due to their extraordinary high carbon capture (sequestration) and storage capacity in sediments (Duarte et al., 2005; McLeod et al., 2011; Fourqurean et al., 2012; Ricart et al., 2015; Atwood et al., 2017), frequently termed "blue carbon". VCHs also provide other important ecosystem services such as protecting coastal areas against erosion (Ward et al., 1984; Fonseca and Cahalan, 1992) and increasing marine biodiversity (Unsworth and Cullen-Unsworth, 2017). Nevertheless, VCHs are being lost and existing in degraded conditions due to conversion to alternative land-uses (Alongi, 2002), large-scale physical damage [e.g., dredging, dragging and urban development (Fonseca et al., 1984; Peterson et al., 1988; Neckles et al., 2005)] and degradation [e.g., moorings (Unsworth et al., 2017)] and increased land run-off and sedimentation (Brodersen et al., 2017a), putting essential ecosystem services at risk.

Sediments of VCHs are generally considered anoxic due to high organic carbon input and microbial activity (Blaabjerg et al., 1998; Hansen et al., 2000; Nielsen et al., 2001; Holmer and Laursen, 2002) and slow diffusion of $\mathrm{O}_{2}$ from seawater into the porewater. The high microbial activity is driven by large pools of organic material originating from the plants themselves (Miyajima et al., 1998) or as a result of increased sedimentation capturing organic material from the water column and adjacent land catchments (Burdige, 2005). Sedimentary carbon occurs in the form of both particulate organic carbon (e.g., plant material) and dissolved organic carbon (DOC) (e.g., root/rhizome exudates). Microbes in the aerobic surface sediment breakdown a large fraction of this carbon and ultimately convert it into dissolved inorganic carbon, i.e., $\mathrm{CO}_{2}, \mathrm{HCO}_{3}{ }^{-}$and $\mathrm{CO}_{3}{ }^{2-}$ (Fenchel et al., 1998), termed microbial carbon remineralization. However, in the absence of $\mathrm{O}_{2}$ introduction at depth by plant roots (termed radial $\mathrm{O}_{2}$ loss) or burrowing animals, transport of gasses and solutes across the surface of cohesive sediments occurs through the diffusive boundary layer $(\mathrm{DBL})$, a thin water layer in which molecular diffusion is the only means of transport (Jørgensen and Revsbech, 1985). Microbial respiration strongly affects the supply of $\mathrm{O}_{2}$ to the sediment, particularly in finegrained sediment and low-energy environments where advective $\mathrm{O}_{2}$ supply is less important (Burdige, 2011). Consequently, high rates of microbial activity in the sediment surface deplete $\mathrm{O}_{2}$ within a few millimeters of the sediment surface (Jørgensen and Revsbech, 1985), where after the sediment become anoxic and highly reduced (Canfield et al., 1993). Respiratory products of anaerobic metabolism in the anoxic part of the sediment include sulfide $\left(\mathrm{S}^{2-}\right)$, pyrite $\left(\mathrm{FeS}_{2}\right)$ or diagenetically produced organic sulfur, dinitrogen $\left(\mathrm{N}_{2}\right)$, ammonium $\left(\mathrm{NH}_{4}{ }^{+}\right)$, methane $\left(\mathrm{CH}_{4}\right)$, and other products (Burdige, 2011).

The characteristic physico-chemical micro-gradients of the uppermost sediment layers determines the metabolic capacity of the microbes inhabiting vegetated coastal sediments, which in turn can control the fate of carbon within the sediments (other factors likely controlling carbon sequestration include climate, bathymetry and flow regime; see Belshe et al., 2017). The presence or absence of $\mathrm{O}_{2}$ directly determines which metabolic pathways and enzymes can be used for carbon degradation (Heider and Fuchs, 1997). In oxic environments, large recalcitrant molecules, such as lignin polymers, are degraded through hydrolysis whereby organic molecules are broken down to smaller, more readily-degradable molecules facilitated by a group of enzymes named hydrolytic mono- or di-oxygenases (Heider and Fuchs, 1997). In anoxic sediments, degradation of complex recalcitrant molecules, such as lignocellulose, usually occurs at much lower rates through various reductive processes (Evans, 1977; Benner et al., 1984; Heider and Fuchs, 1997; Boll et al., 2002). Oxygen exposure therefore strongly affects how much recalcitrant carbon gets degraded (Hartnett et al., 1998). In the thin oxic surface layer of the sediment, aerobic heterotrophs gain energy by oxidizing carbon with $\mathrm{O}_{2}$ as the electron acceptor. Below this oxic layer, diverse microbial populations use a variety of alternative electron acceptors for catabolic reactions, such as $\mathrm{NO}_{3}{ }^{-}, \mathrm{Mn}^{4+}, \mathrm{Fe}^{3+}$, and $\mathrm{SO}_{4}{ }^{2-}$ (Fenchel et al., 1998). Sulfate reduction is generally the dominant microbial process in anoxic, marine sediments (Jørgensen, 1982), where $\mathrm{H}_{2} \mathrm{~S}$ is produced using $\mathrm{SO}_{4}{ }^{2-}$ as an electron acceptor, and can thus be used as a proxy for the overall anaerobic microbial activity and carbon turnover rate in the sediment (Jørgensen, 1982; Canfield et al., 1993). This is also true for VCHs, such as seagrass sediments, where sulfate-reducing bacteria (SRB) are often the most abundant microbial functional group (Welsh, 2000; Jensen et al., 2007; Cúcio et al., 2016). The activity of SRB at and around the oxic/anoxic interfaces, such as in the rhizosphere of plants, results in steep gradients of phytotoxic $\mathrm{H}_{2} \mathrm{~S}$ below the oxidized zone of the sediment (e.g., Brodersen et al., 2014; Schrameyer et al., 2018).

Many wetland plants, including seagrasses, salt marsh and mangrove plants, release DOC (Moriarty et al., 1986; Pollard and Moriarty, 1991) and $\mathrm{O}_{2}$ into the rhizosphere from roots and the rhizome (Pedersen et al., 1998; Koren et al., 2015; Brodersen et al., 2015b, 2016; Koop-Jakobsen et al., 2018). Exudate DOC can be easily degraded by microbes both within the oxic and anoxic sediments and thus lead to local stimulation 
of the microbial community (Isaksen and Finster, 1996; Blaabjerg and Finster, 1998; Blaabjerg et al., 1998; Hansen et al., 2000; Nielsen et al., 2001; Alongi, 2005; Lovell, 2005), which results in high microbial respiration rates in the surface sediment (and plant rhizosphere) and thus high sediment $\mathrm{O}_{2}$ demand. In this way, VCHs can modulate their surrounding below-ground environment to solubilize nutrients (Alongi, 2005; Lovell, 2005; Long et al., 2008; Pagès et al., 2011; Brodersen et al., 2017b) and oxidize SRB-formed phytotoxic sulfide (Brodersen et al., 2015b, 2017b). However, a cross-ecosystem comparison of the key biogeochemical processes and chemical conditions within sediments of VCHs in the context of carbon remineralization and sequestration, and how the sediment processes may be affected by physical disturbance, are rare despite being needed to understand organic carbon sequestration and cycling in $\mathrm{VCHs}$ (Belshe et al., 2017). Physical disturbance of VCHs can lead to a reduction in sediment organic carbon stocks (Bourque et al., 2015), likely via $\mathrm{O}_{2}$ exposure of sub-surface sediment layers and the subsequent stimulation of microbial activity (Macreadie et al., 2015; Trevathan-Tackett et al., 2018a,b).

In this study, we measured $\mathrm{O}_{2}$ consumption and sulfate reduction rates (i.e., estimates of the aerobic and anaerobic microbial activity) within sediments of seagrass, salt marsh and mangrove ecosystems from the Sydney area, New South Wales, Australia in order to characterize the chemical conditions that could ultimately influence the efficiency of carbon sequestration. Sediment samples were divided into "surface" cores and "deep" cores to compare the activity of the microbial community within the two different sediment layers after experimental exposure to $\mathrm{O}_{2}$, approximately simulating undisturbed and physically exposed sediments, respectively. We hypothesized that surface sediments will have higher microbial activity, and thereby higher rates of $\mathrm{O}_{2}$ consumption and sulfate reduction, than deeper sediment layers due to differences in the availability of readily degradable organic carbon (Costa et al., 2007). In contrast, "deep" (previously anoxic) sediment layers will be susceptible to $\mathrm{O}_{2}$ intrusion and thus dispersal and settlement of facultative (or obligate) aerobes; potentially increasing remineralization of deep VCH carbon stocks. Detailed information on key biogeochemical processes within surface and deep and newly exposed sediment layers is important for predicting the potential carbon sequestration capacity for the ecosystems in question and can provide means for better guidance of coastal management and protection (Macreadie et al., 2017; Lovelock et al., 2017; Trevathan-Tackett et al., 2017).

\section{MATERIALS AND METHODS}

\section{Study Site and Sediment Core Sampling}

Sediments from VCHs were collected from the sub-tropical east coast of New South Wales near Sydney, Australia in the summer in February 2014. Mangrove and salt marsh sediment cores were collected at Towra Point in Botany Bay, NSW, Australia $\left(34.0064{ }^{\circ} \mathrm{S}, 151.1653^{\circ} \mathrm{E}\right)$. Avicennia marina was the dominant species at the mangrove site, whereas the salt marsh site was a mixture of Juncus kraussii and Sarcocornia quinqueflora.
Towra Point consists of a sandy peninsular largely isolated from terrestrial influence, with a salinity of $32 \pm 3$ (mean \pm SD) in nearby open water (Geoscience Australia, 2015). Seagrass sediment cores were collected at Fagans Bay, NSW, Australia $\left(33.4345^{\circ} \mathrm{S}, 151.3223^{\circ} \mathrm{E}\right)$, where the sole seagrass species was Zostera muelleri. Fagans Bay sits at the mouth of Narara Creek and typically has salinities ranging from 25 to 30 , however, it is subject to salinity fluctuations during flooding or drought periods (Collier and Mackenzie, 2008). All sediment cores where collected intertidally at low tide (tidal range from $\sim 0.2$ to $1.2 \mathrm{~m}$ ) near the rhizomes and roots and no belowground plant material was removed. Sediments were collected in triplicate with openbarrel push cores made of PVC pipes $(200 \mathrm{~cm}$ length, $5 \mathrm{~cm}$ internal diameter), which were pushed into the sediments until refusal was reached (Figure 1). Expanding rubber plugs were then inserted into the top-end of the PVC pipes to achieve internal suction while retrieving the sediment cores. Sediment cores were then returned to the shore and sliced intact into smaller $10 \mathrm{~cm}$ sections with depth ("surface" $=0-10 \mathrm{~cm}$ depth core section; "deep" = a $10 \mathrm{~cm}$ interval from a depth $>50 \mathrm{~cm}$ ) using a reciprocating saw. All core sections were capped with PVC caps within $60 \mathrm{~s}$ of sectioning to reduce $\mathrm{O}_{2}$ exposure to sediments and returned to the laboratory for incubation.

\section{Experimental Design}

Laboratory incubations were established in mesocosms (32 L, rectangular tanks) at the University of Technology Sydney (UTS), Sydney, Australia following Macreadie et al., (unpublished Figure 1). Surface and deep sediment cores were incubated in the dark under $\sim 26^{\circ} \mathrm{C}$ (resembling water temperatures around Sydney during summer-time), a salinity of $\sim 35$ and $100 \%$ air saturation in the water column in the large seawater reservoirs for 90 days (flushed and refilled with fresh seawater twice daily and continuously monitored; Macreadie et al., unpublished). The deep cores were incubated this way to simulate physical exposure as a result of disturbance (e.g., a dredging operation and/or dragging event) and to expose the new sediment surface layers to oxic conditions for a longer time period to allow for potential dispersal and settlement of facultative aerobes. While exposing the sediments to different tidal regimes would be more representative of natural inundation conditions, simulated tidal conditions would preclude us from making cross-habitat comparisons on the effect of $\mathrm{O}_{2}$ exposure; therefore, all sediment treatments were standardized to full inundation. Water column $\mathrm{O}_{2}$ status was maintained by air bubbling using an air stone connected to an air pump, and continued water flow was ensured using water pumps.

\section{Sediment Organic Carbon Content}

Measurement of organic carbon content $\left(\mathrm{C}_{\text {org }}\right)$ within sediments was done following procedures described by Campbell et al. (2014). In brief, after the 90 days mesocosm incubation bulk sediment samples $\left(10 \mathrm{~cm}\right.$ thick) were dried at $60^{\circ} \mathrm{C}$ to a constant weight. Cores were subsampled at $1 \mathrm{~cm}$ intervals to $2 \mathrm{~cm}$ depth and dried. Dry bulk density (g dry weight/volume) was calculated before the sediments were ground using a ball mill and split into two equal parts. A Costech 410 Elemental Analyzer was used to 


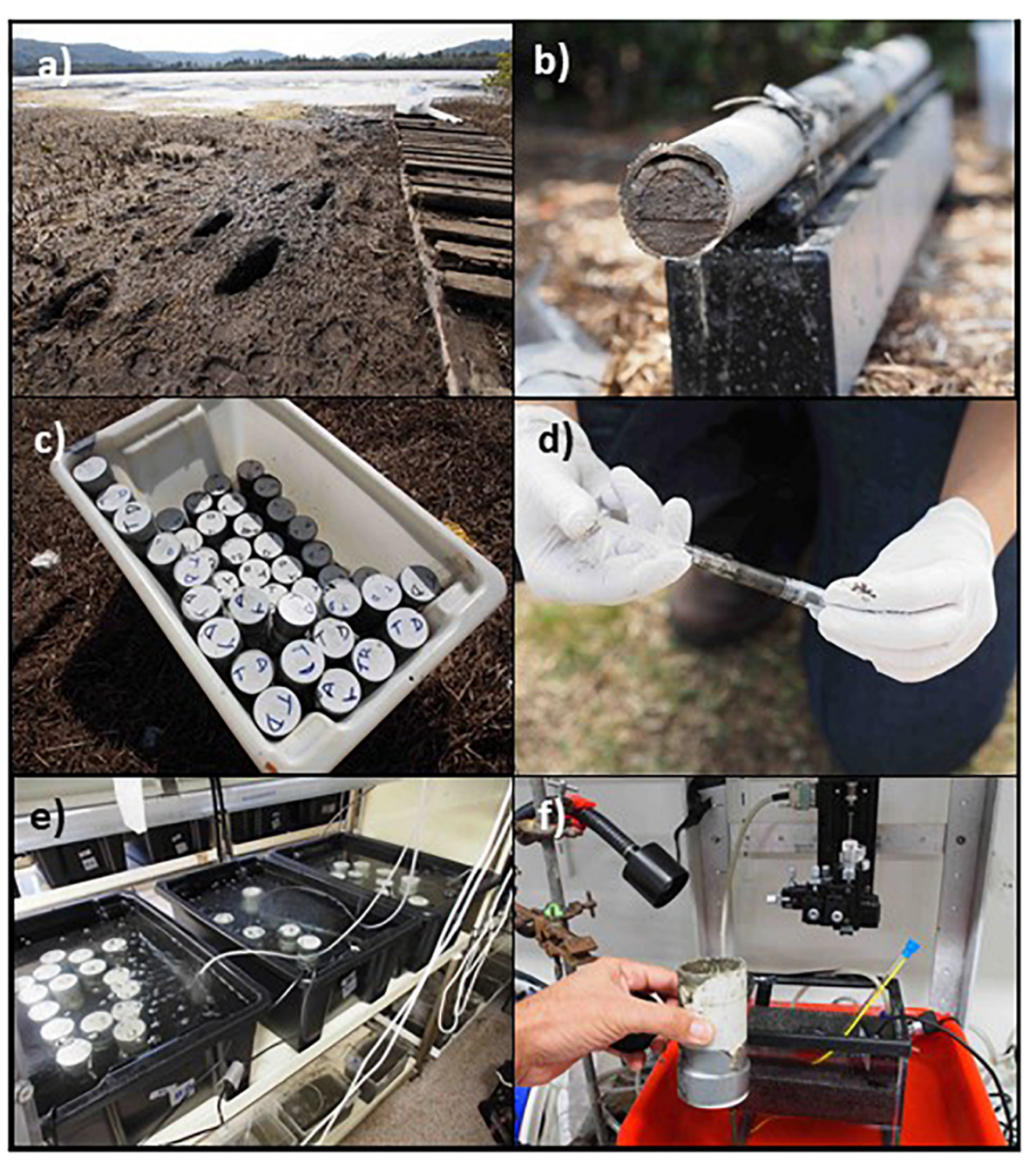

FIGURE 1 | Experimental design and sediment sampling. Pictures shows (a) the Fagans Bay study site at low tide; (b) full-length core undergoing sectioning; (c) collection of sectioned cores; (d) syringe corer extruding sediment for further analyses (incl. porosity determinations); (e) cores undergoing incubation in laboratory mesocosms; and (f) the microsensor setup for profiling $\mathrm{pH}, \mathrm{O}_{2}$ and $\mathrm{H}_{2} \mathrm{~S}$ concentrations in the sediments.

measure the total sediment carbon $\left(\mathrm{TC}_{\text {sediment }}\right.$ ) of the first set of duplicates. The second set of duplicates was ashed in a muffled furnace at $500^{\circ} \mathrm{C}$ for $6 \mathrm{~h}$ before analysis on the elemental analyser to determine the inorganic carbon content of the ash $\left(\mathrm{IC}_{a s h}\right)$. The inorganic carbon content of the original sediment $\left(\mathrm{IC}_{\text {sediment }}\right)$ was calculated using the $\mathrm{IC}_{a s h}$ value back-calculated from the original weight of the un-ashed sample. Finally, we calculated $\mathrm{C}_{\text {org }}(\%$ dry weight; mean $\pm \mathrm{SEM} ; n=6$ ) as the following:

$$
\mathrm{C}_{\text {org }}=\mathrm{TC}_{\text {sediment }}-\mathrm{IC}_{\text {sediment }}
$$

\section{Microsensor Profiling}

Microsensor profiling characterized the chemical environment within the top 0-3 cm of three replicate "surface" and "deep" sediment cores (Figure 1). Prior to profiling, each sediment core was submerged in a small $(2 \mathrm{~L})$ aquarium with seawater, which itself was positioned in a water bath preheated to $\sim 26^{\circ} \mathrm{C}$ via a submersible aquarium heater (Sonpar Aquarium Equipment,
China). Water aeration in the aquarium was ensured and maintained via a continuous flow of air from a submerged air-stone connected to an air pump. Water movement was achieved with a small water pump attached to the aquarium wall and adjusted to a height that allowed for sufficient water flow across the sediment surface (i.e., continuous movement of organic particles, but no movement of larger sand particles). Each sediment core was incubated in the aquarium for at least $20 \mathrm{~min}$ at constant flow after moving from the incubation tank (Figure 1e) to the microprofiling station (Figure 1f) in order to settle before profiling commenced to ensure steady state profiles in the sediment (as confirmed by repeated microsensor profiles).

Oxygen $\left(\mathrm{O}_{2}\right)$, hydrogen sulfide $\left(\mathrm{H}_{2} \mathrm{~S}\right)$ and $\mathrm{pH}$ microprofiles were measured in individual sediment cores with Clark-type $\mathrm{O}_{2}$ microsensors (Revsbech, 1989) and $\mathrm{H}_{2} \mathrm{~S}$ microsensors (Jeroschewski et al., 1996; Kühl et al., 1998) (tip diameter $=100 \mu \mathrm{m}, 90 \%$ response time $<8$ and 6 s, respectively, stirring sensitivity <1\%; Unisense A/S, Aarhus, Denmark) 
and a pH microelectrode (e.g., Kühl and Revsbech, 2001) (tip diameter $=500 \mu \mathrm{m}, 90 \%$ response time $<10 \mathrm{~s}$; Unisense $\mathrm{A} / \mathrm{S}$, Denmark; linear range $\mathrm{pH} 4-9$; signal to $\mathrm{pH}$ ratio $>50 \mathrm{mV} / \mathrm{pH}$ unit). The $\mathrm{pH}$ microelectrode was used in combination with an external standard $2 \mathrm{~mm}$ reference electrode (Ionode LLC, Australia) immersed in the aquarium seawater. All three sensor types were connected to a 4-channel microsensor multimeter (Unisense A/S, Denmark), interfaced with a laptop computer running dedicated data acquisition and microsensor positioning software (SensorTrace Pro v.3.1.1, Unisense A/S, Denmark). Microsensors were mounted on a motorized micromanipulator (Unisense A/S, Denmark), one sensor at a time, and the micromanipulator itself was mounted on a heavy metal stand to avoid vibrations. Each microsensor was linearly calibrated from signal readings (2- to 4-point calibrations) at experimental temperature and salinity before microprofiling commenced (full calibration procedures are provided on the manufactures website $\left.^{1}\right)$. Briefly, the $\mathrm{O}_{2}$ microsensors were calibrated in $0 \%$ (obtained by flushing seawater with dinitrogen gas and/or by adding an oxygen scavenger, such as sodium dithionite) and $100 \%$ air-saturated seawater. The $\mathrm{H}_{2} \mathrm{~S}$ microsensors were calibrated in anoxic, acidic $(\mathrm{pH} 4) \mathrm{H}_{2} \mathrm{~S}$ solutions (i.e., 0, 50, 100, $250 \mu \mathrm{M} \mathrm{H}_{2} \mathrm{~S}$ ). The $\mathrm{pH}$ microelectrodes were calibrated in buffers with a known $\mathrm{pH}$ of 4,7 , and 10 . Prior to calibration, the Clark-type $\mathrm{O}_{2}$ microsensors were pre-contaminated with sulfide to avoid drifting signals during measurements (Brodersen et al., 2015a).

For each depth profile, the tip of the respective microsensor was positioned at the sediment surface (defined as $0 \mu \mathrm{m}$ depth on graphs) by means of a manual micromanipulator, while observing the sensor tip and the sediment surface through a stereo-microscope (AmScope, Irvine, CA, United States) mounted on an articulating arm (SM-6TZ; Amscope, Irvine, CA, United States). Measurements were done starting at a set distance from the sediment surface and then measured in vertical depth increments of $100 \mu \mathrm{m}$ for $\mathrm{O}_{2}$ profiles, and 500 or $1000 \mu \mathrm{m}$ for $\mathrm{H}_{2} \mathrm{~S}$ and $\mathrm{pH}$ profiles, respectively, down to a maximum vertical depth of $\sim 25 \mathrm{~mm}$ depending on the sediment $\mathrm{O}_{2}$ consumption and the depth of the sulfide front, controlled through the position and data acquisition software (SensorTrace Pro; Unisense A/S). Three replicate profiles were done with each microsensor at various random locations in each sediment core while avoiding the very edges to limit edge effects and areas of complex flow. Finally, the three depth profiles within each sediment core were averaged to produce one replicate depth profile for each replicate sediment core per microsensor (i.e., $n=2-3$, sediment core replicates; $n=6-9$, microsensor profile replicates; note, one sediment core replicate was excluded from the seagrass-inhabited "surface" sediment, because the sediment core had fallen over during incubation).

\section{Flux Calculations}

Net $\mathrm{O}_{2}$ and total sulfide $\left(\mathrm{S}_{t o t}{ }^{2-}\right)$ fluxes were calculated via Fick's first law of diffusion based on the slope of the linear change in

${ }^{1}$ www.unisense.com concentration with depth:

$$
J=-\Phi \times \mathrm{D}_{0} \times \frac{\partial \mathrm{C}}{\partial \mathrm{z}} .
$$

where $J$ is the flux ( $\mathrm{nmol} \mathrm{cm} \mathrm{cm}^{-2} \mathrm{~s}^{-1}$ ) of the compound, $\Phi$ (dimensionless) is the porosity of the medium (here seawater or sediment), $D_{0} \quad\left(\mathrm{~cm}^{2} \mathrm{~s}^{-1}\right)$ is the molecular diffusion coefficient for the respective molecule in seawater at the experimental temperature and salinity, and $\partial C\left(\mathrm{nmol} \mathrm{cm} \mathrm{cm}^{-3}\right)$ is the linear change in concentration over the distance $\partial z$ (cm). Specifically, net $\mathrm{O}_{2}$ fluxes [termed diffusive $\mathrm{O}_{2}$ uptake (DOU)] were calculated from the slope of the linear change in $\mathrm{O}_{2}$ concentration in the diffusive boundary layer just above the sediment surface (Jørgensen and Revsbech, 1985), with $\Phi=1$ (water) and $D_{0, O 2}=2.29 \cdot 10^{-5} \mathrm{~cm}^{2} \mathrm{~s}^{-1}$ at a temperature of $26^{\circ} \mathrm{C}$ and a salinity of 35 (values obtained from Unisense gas table; Ramsing and Gundersen, 1994 "Seawater and gasses-Tabulated physical parameters of interest to people working with microsensors in marine systems"1). The net fluxes of total sulfide were calculated from the bottom linear segment of the sulfide concentration profile in the sediment, with $\Phi=0.65$ (mangrove), 0.60 (salt marsh), 0.51 (seagrass) in surface sediment cores and 0.59 (mangrove), 0.58 (salt marsh), 0.72 (seagrass) in deep sediment cores, and the apparent diffusivity of $\mathrm{H}_{2} \mathrm{~S}$ molecules calculated as $D_{0, H 2 S}=0.7573 \times D_{0, O 2}=1.73 \times 10^{-5} \mathrm{~cm}^{2} \mathrm{~s}^{-1}$ (conversion factor to calculate the diffusivity of $\mathrm{H}_{2} \mathrm{~S}$ was taken from the Unisense gas table). As the $\mathrm{H}_{2} \mathrm{~S}$ microsensor is only sensitive to the gaseous $\mathrm{H}_{2} \mathrm{~S}$ component of the total sulfide pool (defined as $\left.S_{t o t}{ }^{2-}=\left[\mathrm{H}_{2} \mathrm{~S}\right]+\left[\mathrm{HS}^{-}\right]+\left[\mathrm{S}^{2-}\right]\right)$, the speciation of which is directly related to the porewater $\mathrm{pH}$ (Jeroschewski et al., 1996); where dissolved $\mathrm{H}_{2} \mathrm{~S}$ gas predominates at porewater $\mathrm{pH}$ levels below 7 and $\mathrm{HS}^{-}$predominates at higher $\mathrm{pH}$ levels. The total sulfide concentration was calculated for each $\mathrm{H}_{2} \mathrm{~S}$ measurement as described in Jeroschewski et al. (1996) based on the $\mathrm{pH}$ measured in the same vertical depth and region within the sediment. We only used the upward flux of total sulfide to calculate the estimated sulfate reduction rates inside the sediments (Kühl and Jørgensen, 1992); as the sediment cores were sealed at the bottom the downward flux of sulfide can be assumed insignificant. The average volume-specific $\mathrm{O}_{2}$ consumption rate $(\mathrm{R})$ was calculated by dividing the DOU with the measured $\mathrm{O}_{2}$ penetration depth, i.e., $R=\mathrm{DOU} / \mathrm{O}_{2}$ penetration depth (assuming constant reactivity and diffusivity over this depth interval; Frederiksen and Glud, 2006). Calculations were done based on the averaged profiles $(n=3)$ from each sediment core, and the presented fluxes are the average $( \pm 1 \mathrm{SE}, n=3)$ of the three replicate sediment cores. The data for the seagrass microprofiles at day 90 have been shared with another paper where they are used in a different context and only included in the supplementary material (Supplementary Figure S6 in Macreadie et al., unpublished).

\section{Data Analysis}

Two-Way Analysis of Variance (ANOVA) tests in conjunction with Tukey's post hoc tests were performed to assess the 
differences in $\mathrm{O}_{2}$ and total sulfide flux and $\mathrm{O}_{2}$ penetration depth between ecosystem type and sediment depth. Data were log transformed where necessary to meet the assumption of equal variances. In cases where transformation did not improve variance, one-way ANOVAs or independent $t$-tests were performed separately for ecosystem and depth factors.

\section{RESULTS}

\section{Percent Organic Carbon in Surface and Deep Sediments}

The percent organic carbon content $\left(\% \mathrm{C}_{\text {org }}\right)$ of the mangrove, salt marsh and seagrass surface sediments were $4.50 \pm 0.96$, $1.61 \pm 0.52$, and $1.25 \pm 0.26 \%$, which was significantly higher than in the deep sediments (except for in seagrasses) where the $\% \mathrm{C}_{\text {org }}$ amounted to $1.91 \pm 0.76,0.34 \pm 0.05$, and $1.56 \pm 0.09 \%$, respectively $(p<0.05)$. Mangrove sediments had significantly higher $\% \mathrm{C}_{\text {org }}$ than seagrass and salt marsh sediments $(p=0.001)$. No significant difference was found between seagrass and salt marsh sediments.

\section{Depth Microprofiles of $\mathrm{O}_{2}$, Total Sulfide and $\mathbf{p H}$}

$\mathrm{O}_{2}$ was rapidly consumed in the mangrove and seagrass surface sediments $\left(\mathrm{O}_{2}\right.$ penetration depth of $0.8 \pm 0.2 \mathrm{~mm}$ and $1.6 \pm 0.4 \mathrm{~mm}$, respectively), which was contrasted by the salt marsh sediments where $\mathrm{O}_{2}$ penetration was $\sim 5$ times deeper (vertical depth of $5.3 \pm 1.1 \mathrm{~mm}$ ) (Figure 2A and Table 1; depth $\mathrm{x}$ ecosystem interaction for $\mathrm{O}_{2}$ penetration depth, $F_{2,11}=6.482$, $p=0.014$; schematic diagram shown in Figure $2 \mathrm{E}$ ). In the deep sediment, the $\mathrm{O}_{2}$ penetration depth was very similar in all three ecosystems ( $\sim 3 \mathrm{~mm}$ ) (Figure $2 \mathbf{B}$ and Table 1 ); and $\sim 2-3$ times deeper than in the surface sediment for the mangrove and seagrass sediment (Figures 2A,B).

The surface sediment sulfide production was highest in the mangrove samples, indicated by a significantly shallower sulfide front than the other ecosystem sediments $(0.7 \pm 0.2 \mathrm{~mm}$; habitat main effect, $\left.F_{2,16}=10.979, p=0.001\right)$ and high maximum total sulfide concentration $\left(1000 \pm 307 \mu \mathrm{mol} \mathrm{S}_{\text {tot }}{ }^{2-} \mathrm{L}^{-1}\right.$ ) (Figure 2C and Table 1). Salt marsh surface sediments had the lowest sulfide production (sulfide front of $7.3 \pm 1.6 \mathrm{~mm}$, maximum total sulfide concentration of $23 \pm 10 \mu \mathrm{mol} \mathrm{S}_{t o t}{ }^{2-} \mathrm{L}^{-1}$ ), whereas sulfide production in surface seagrass sediments was intermediate (variable sulfide front of 3 and $19 \mathrm{~mm}$, maximum total sulfide concentration of $837 \mu \mathrm{mol} \mathrm{S}_{t o t}{ }^{2-} \mathrm{L}^{-1}$ ) (Figure $2 \mathrm{C}$ and Table 1). In contrast to the surface sediments, the deep sediments showed a shift in the sulfide front and large reduction in maximum total sulfide concentrations for mangrove and seagrass sediments $\left(3.2 \pm 1.2 \mathrm{~mm}\right.$ and $310 \pm 109 \mu \mathrm{mol} \mathrm{S}_{\text {tot }}{ }^{2-}$ $\mathrm{L}^{-1}$, and $6.3 \pm 1.7 \mathrm{~mm}$ and $81 \mu \mathrm{mol} \mathrm{S}$ tot $^{2-} \mathrm{L}^{-1}$, respectively; Figure 2D and Table 1). The sulfide production for deep salt marsh sediments was similar to surface sediments, with the sulfide front $\sim 3 \mathrm{~mm}$ deeper than in the surface sediments and a similar maximum total sulfide concentration $(33 \pm 29 \mu \mathrm{mol}$ $\mathrm{S}_{\text {tot }}{ }^{2-} \mathrm{L}^{-1}$; Figures 2C,D).
Depth microprofiles of $\mathrm{pH}$ showed a pronounced decrease in $\mathrm{pH}$ with depth in all ecosystems (Figure 3). In mangrove surface sediments, $\mathrm{pH}$ dropped from 8.2 at the surface to 6.5 at $4.5 \mathrm{~mm}$ depth (Figure $\mathbf{3 A}$ ). Similar sediment acidification was found in the deeper mangrove sediments with $\mathrm{pH}$ reaching 6.9 at $8.5 \mathrm{~mm}$ depth (Figure 3B). In salt marsh sediments, the sediment acidification with depth was very similar between surface and deep sediment with $\mathrm{pH}$ reaching 6.7 at $17 \mathrm{~mm}$ depth and 6.6 at $20 \mathrm{~mm}$ depth, respectively (Figure 3). In seagrass surface sediments, $\mathrm{pH}$ reached 7.5 at $8 \mathrm{~mm}$ depth where after a small increase in $\mathrm{pH}$ with depth was observed and $\mathrm{pH} 7.1$ at $25 \mathrm{~mm}$ depth in deep sediment (Figure 3).

\section{Areal and Volumetric $\mathrm{O}_{2}$ Consumption Rates}

$\mathrm{O}_{2}$ consumption across the sediment-water interface was significantly higher in the surface sediment as compared to the deep sediment in seagrass and mangrove sediments, as shown by 1.8-5.5-fold higher diffusive $\mathrm{O}_{2}$ uptake (DOU) for surface sediments (Figure 4A). In contrast, no significant change was found between depths for salt marsh sediments (Figure 4A). Comparing across ecosystem types, the DOU of the mangrove surface sediment $\left(102 \pm 17 \mathrm{mmol} \mathrm{O}_{2} \mathrm{~m}^{-2}\right.$ $\left.\mathrm{d}^{-1}\right)$ was significantly higher than both salt marsh $(22 \pm 7$ mmol $\mathrm{O}_{2} \mathrm{~m}^{-2} \mathrm{~d}^{-1}$ ) and seagrass (34 mmol $\mathrm{O}_{2} \mathrm{~m}^{-2} \mathrm{~d}^{-1}$ ) sediments (Figure 4A). In the deeper sediment, the DOU was very similar across all VCHs, approximately $20 \mathrm{mmol} \mathrm{O}_{2} \mathrm{~m}^{-2}$ $\mathrm{d}^{-1}$ (Figure 4A).

The depth-independent volume-specific $\mathrm{O}_{2}$ consumption rate (R) also showed a significantly higher activity at the sediment surface and at the oxic/anoxic interface below in the mangrove sediments $\left(122 \pm 21 \mathrm{~mol} \mathrm{O}_{2} \mathrm{~m}^{-3} \mathrm{~d}^{-1}\right)$ as compared to the salt marsh $\left(4 \pm 1 \mathrm{~mol} \mathrm{O}_{2} \mathrm{~m}^{-3} \mathrm{~d}^{-1}\right)$ and seagrass $\left(22 \mathrm{~mol} \mathrm{O}_{2}\right.$ $\mathrm{m}^{-3} \mathrm{~d}^{-1}$ ) sediments (Figure 4B). As for the DOU, the volumespecific $\mathrm{O}_{2}$ consumption rates of the deep sediment were similar across sediments from the different $\mathrm{VCH}$ and amounted to approximately $7 \mathrm{~mol} \mathrm{O}_{2} \mathrm{~m}^{-3} \mathrm{~d}^{-1}$ (Figure 4B).

\section{Estimated Sulfate Reduction Rates}

The estimated sulfate reduction rates (SRR) were significantly different among ecosystems (Figure 4C). Specifically, the SRR activity for mangrove surface sediment was 11-400 times higher and deep sediment 29-94 times higher than seagrass and salt marsh sediments, respectively (Figure 4C). In salt marsh sediments SRR was negligible, for both depths, with maximum rates of $\sim 0.2 \pm 0.2 \mathrm{mmol} \mathrm{S}_{\text {tot }}{ }^{2-} \mathrm{m}^{-2} \mathrm{~d}^{-1}$ (Figure $4 \mathrm{C}$ ). In contrast, SRR was higher in the surface sediments compared to deep sediments in both mangrove and seagrass sediments $(\sim 3-$ 9-fold difference; Figure 4C). The averaged estimated sulfate reduction rate of the mangrove surface sediment was $57 \pm 9$ mmol $\mathrm{S}_{\text {tot }}{ }^{2-} \mathrm{m}^{-2} \mathrm{~d}^{-1}$ as compared to $5 \mathrm{mmol} \mathrm{S}_{\text {tot }}{ }^{2-} \mathrm{m}^{-2} \mathrm{~d}^{-1}$ in seagrass surface sediment (Figure 4C). In the deep sediment, the estimated sulfate reduction rate amounted to $17 \pm 8 \mathrm{mmol}$ $\mathrm{S}_{\text {tot }}{ }^{2-} \mathrm{m}^{-2} \mathrm{~d}^{-1}$ and $1 \pm 0 \mathrm{mmol} \mathrm{S}_{\text {tot }}{ }^{2-} \mathrm{m}^{-2} \mathrm{~d}^{-1}$ in mangrove and seagrass sediment, respectively (Figure 4C). 
A

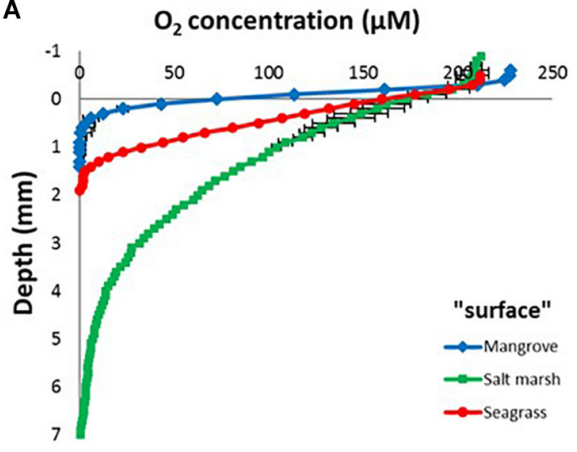

C

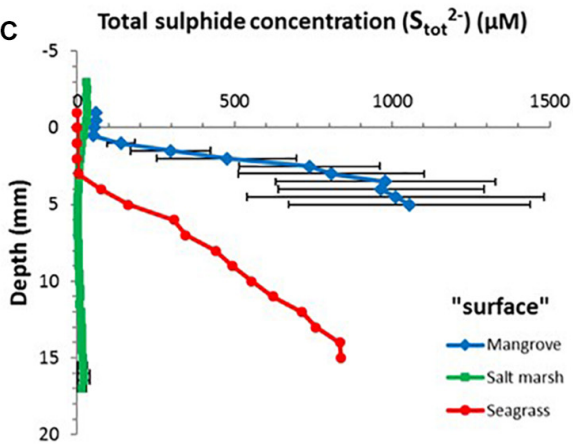

B

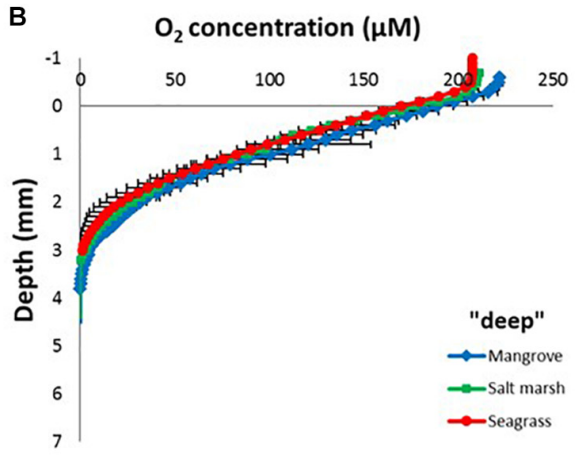

$D_{-5}$

Total sulphide concentration $\left(\mathrm{S}_{\text {tot }}^{2-}\right)(\mu \mathrm{M})$
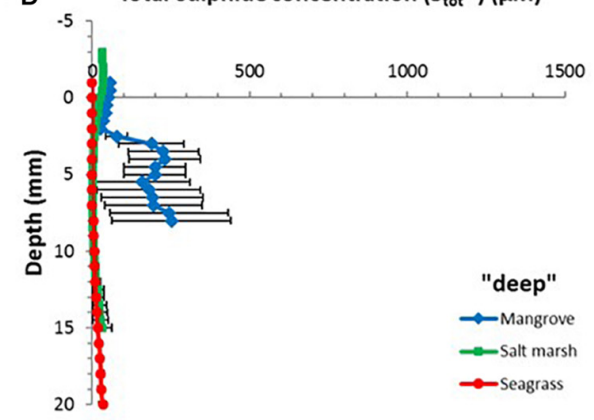

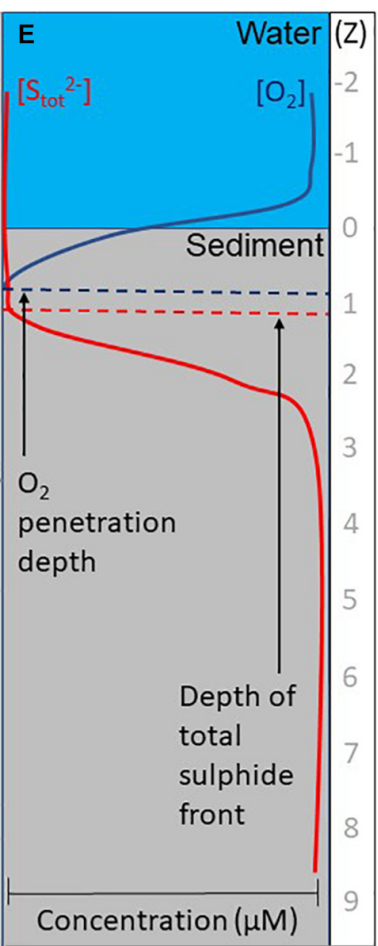

FIGURE 2 | Depth microprofiles of the $\mathrm{O}_{2}$ and total sulfide $\left(\mathrm{S}_{\text {tot }}{ }^{2-}\right.$ ) concentration within sediments originating from mangrove, salt marsh, and seagrass ecosystems (Sydney area, NSW, Australia). (A) $\mathrm{O}_{2}$ microsensor measurements in the sediment surface ("surface"; 0-10 cm depth). (B) $\mathrm{O}_{2}$ microsensor measurements in deeper sediment layers ("deep"; $>50 \mathrm{~cm}$ depth). Microsensor profiling was performed down to 1 to $2 \mathrm{~cm}$ depth within each sediment core, depending on the sediment $\mathrm{O}_{2}$ consumption. (C) Total sulfide measurements in the sediment surface ("surface"; 0-10 cm depth). (D) Total sulfide measurements in deeper sediment layers ("deep"; $>50 \mathrm{~cm}$ depth). Microsensor profiling was performed within the top 0-2 cm depth of each "surface" and "deep" sediment core, depending on the sulfide concentration. The total sulfide concentration was calculated from the measured $\mathrm{H}_{2} \mathrm{~S}$ and $\mathrm{pH}$ microprofiles, as shown previously by Kühl and Jørgensen (1992). Legends depicts the investigated vegetated coastal habitat $(\mathrm{VCH})$. Symbols and lines represent mean values $\pm \mathrm{SEM} ; n=6-9$, technical replicates (biological replication of 2-3). (E) Schematic diagram of $\mathrm{O}_{2}$ and total sulfide microprofiles in sediment, showing examples of the $\mathrm{O}_{2}$ penetration depth and thus the oxic/anoxic interface, as well as, the depth of the sulfide front. $Z$ indicates the vertical sediment depth in $\mathrm{mm}$.

TABLE $1 \mid \mathrm{O}_{2}$ penetration depth and depth of total sulfide front within the investigated vegetated coastal habitats (i.e., seagrass meadow, salt marsh and mangrove ecosystems originating from the Sydney area, NSW, Australia).

\begin{tabular}{|c|c|c|c|c|}
\hline \multirow[t]{2}{*}{ Ecosystem } & \multicolumn{2}{|c|}{$\begin{array}{c}\mathrm{O}_{2} \text { penetration depth } \\
(\mathrm{mm})\end{array}$} & \multicolumn{2}{|c|}{$\begin{array}{l}\text { Depth of sulfide front } \\
\qquad(\mathrm{mm})\end{array}$} \\
\hline & Surface & Deep & Surface & Deep \\
\hline Mangrove & $0.8 \pm 0.2$ & $2.7 \pm 0.6$ & $0.7 \pm 0.2$ & $3.2 \pm 1.2$ \\
\hline Salt marsh & $5.3 \pm 1.1$ & $3.3 \pm 0.1$ & $7.3 \pm 1.6$ & $10.3 \pm 1.7$ \\
\hline Seagrass & 1.6 & $2.9 \pm 0.3$ & 11 & $6.3 \pm 1.7$ \\
\hline
\end{tabular}

Surface, sediment surface $(0-10 \mathrm{~cm}$ depth); deep, deeper sediment layers $(10 \mathrm{~cm}$ core section from $>50 \mathrm{~cm}$ depth). Values represent mean \pm standard error of the mean (SEM, $n=2-3)$.

\section{DISCUSSION}

This study aimed to identify how biogeochemical conditions varied across seagrass, mangrove and salt marsh sediment in the Sydney area (NSW, Australia), in order to assess how the different conditions may affect organic carbon $\left(\mathrm{C}_{\text {org }}\right)$ cycling. The controlled laboratory experimental design allowed us to standardize $\mathrm{O}_{2}$ exposure via full inundation and continued water flow. However, the power to control these conditions limits several naturally occurring variables that could also influence the sediment biogeochemistry, including tidal inundation, flow regime, daily or seasonal temperature, water-column $\mathrm{O}_{2}$ and light shifts and the effects of plant exudation, bioturbation and infauna. Taking into consideration the experimental design and the subsequent constraints of the data interpretation, our results provide valuable insight into how micro-scale biogeochemical processes and chemical conditions can affect carbon sequestration and storage. First, we show that mangrove and seagrass sediments had higher microbial activity in the surface sediments than the salt marsh sediments. Additionally, 

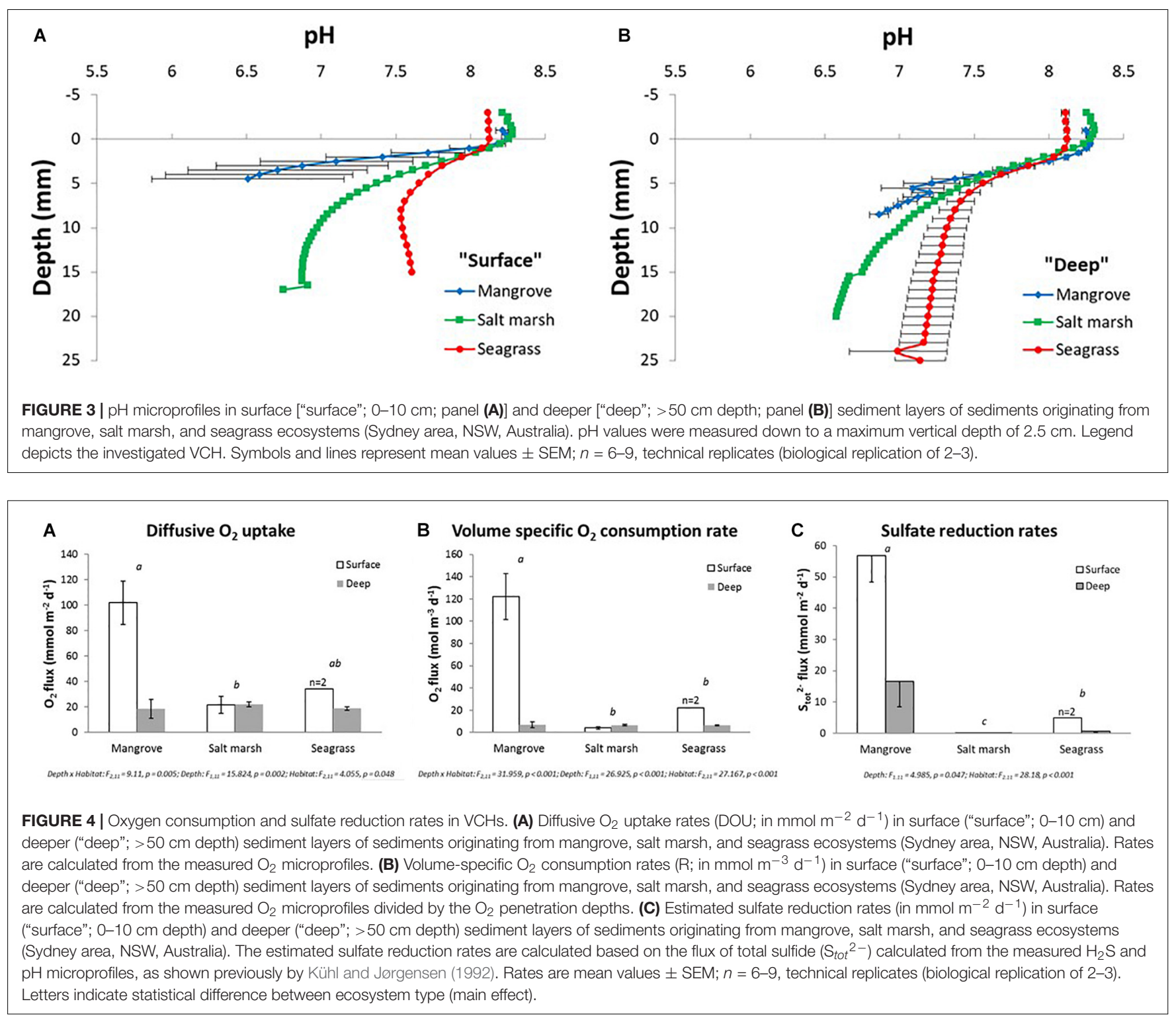

the microbes in surface sediments seemed more active compared to deeper sediments in both seagrass and mangrove ecosystems. In salt marsh sediments, however, metabolic activity seemed similar among depths. As a result of the rapid microbial consumption of $\mathrm{O}_{2}$ within the first few millimeters of the undisturbed surface sediments and the reduced microbial activity in the deeper sediments, anoxic acidic sediment conditions could be ideal for accumulating and storing carbon in these ecosystems. However, exposure of deep sediments to $\mathrm{O}_{2}$ due to physical disturbance can stimulate aerobic metabolism, which could potentially reduce the carbon stocks of these exposed sediment layers.

\section{$\mathrm{O}_{2}$, Sulfide and $\mathrm{pH}$ Distributions}

$\mathrm{O}_{2}$ was rapidly consumed within the first millimeters of the surface sediment of mangrove and seagrass ecosystems, and generally did not penetrate below $7 \mathrm{~mm}$ depth in any ecosystem. Sedimentary $\mathrm{O}_{2}$ is consumed by microbial respiration and through chemical oxidation of reduced solutes that diffuse up from anoxic sediment layers below (Rasmussen and Jørgensen, 1992). The prevailing anoxic sediment conditions likely represents ideal chemical conditions for carbon burial as $\mathrm{O}_{2}$ availability increases the degradation rate of recalcitrant carbon due to, e.g., the activation of aggressive mono- and dioxygenases enzymes in aerobic bacteria (Heider and Fuchs, 1997). This likely contributes to the high carbon sequestration rate observed in $\mathrm{VCHs}$, where below-ground tissues are growing in largely anoxic sediment and therefore seldom exposed to oxic conditions during degradation (e.g., Frederiksen and Glud, 2006; Kristensen et al., 2008; Colmer et al., 2013; Brodersen et al., 2014, 2015a,b, 2017b; Koop-Jakobsen et al., 2017). These findings also correlate with the significantly higher percent organic carbon content $\left(\% \mathrm{C}_{\text {org }}\right)$ found in the mangrove sediments compared to the seagrass and salt marsh sediments in this study. Hence, 
burial of carbon in the deeper sediment layers of VCHs is most likely a result of the aerobic respiration processes in the surface sediment occurring at a slower rate than the high inputs of organic matter to the system (carbon in $>$ carbon out; see also, e.g., Kristensen et al., 2008 and references therein).

The surface sediment of mangrove and seagrass ecosystems were characterized by high total sulfide concentrations that increased with depth below the oxic/anoxic interface and were similar to levels found in densely vegetated seagrass meadows (Borum et al., 2005). However, in some scenarios, the concentrations found in this study were close to reported phytotoxic levels that cause reduced aboveground production or death for VCHs $\left(\geq 500 \mu \mathrm{mol} \mathrm{L}{ }^{-1}\right.$ for A. marina mangroves and Salicornia salt marsh species and $>600 \mu \mathrm{mol} \mathrm{L^{-1 }}$ for Zostera seagrass species; Lamers et al., 2013 and references herein). In naturally vegetated areas, the $\mathrm{O}_{2}$ from the plant roots would help prevent sulfide intrusion into the plant, but this defense against phytotoxicity is regulated by the daylight hours, hypersalinity and the water-column $\mathrm{O}_{2}$ availability (Pedersen et al., 2004; Brodersen et al., 2015b, 2017b; Koren et al., 2015; Johnson et al., 2018). There was a pronounced reduction in the maximum total sulfide concentration in the deep sediment of mangrove and seagrass ecosystems by a factor of 4 to 24 , respectively, which can be explained by less easily degradable carbon in the deeper sediment layers (Burdige, 2007; Costa et al., 2007). In the salt marsh sediments, the maximum total sulfide concentration only reached $33 \mu \mathrm{mol} \mathrm{S} \mathrm{S}_{t o t}{ }^{2-} \mathrm{L}^{-1}$, which is far below the reported phytotoxic levels for salt marsh plants $\left(\geq 500 \mu \mathrm{mol} \mathrm{L}^{-1}\right.$; Lamers et al., 2013 and references herein) and below what generally is reported for salt marsh ecosystems (Howarth and Teal, 1979; Howarth and Giblin, 1983; Koch et al., 1990). It is therefore unlikely that the measured sediment sulfide levels would have led to reduced photosynthesis (i.e., lower DOC), growth and/or enhanced mortality rates [i.e., higher particulate organic carbon (POC)] potentially affecting the total organic matter input in any of the investigated coastal ecosystems.

We observed pronounced sediment acidification with depth in all investigated VCHs and sediment depths; with the lowest $\mathrm{pH}$ values $(\mathrm{pH}$ of $<7$ ) recorded in the mangrove and salt marsh sediments. This acidification of the sediment is likely due to $\mathrm{O}_{2}$-driven chemical oxidation of sediment-produced $\mathrm{H}_{2} \mathrm{~S}$, as the chemical reaction between $\mathrm{O}_{2}$ and $\mathrm{H}_{2} \mathrm{~S}$ generates protons (Nielsen et al., 2006) in combination with $\mathrm{CO}_{2}$ release from microbial respiration (Soetaert et al., 2007). The low $\mathrm{pH}$ in the surface layers (down to $\mathrm{pH}$ of 6.5 ) just below the oxic/anoxic interface of the investigated mangrove and salt marsh sediments may inhibit the growth of some microbial taxa or groups, such as the bacterial phylum Bacteroidetes (Lauber et al., 2009; Thomas et al., 2011), with a decrease of up to $\sim 50 \%$ in relative abundance as compared to at a $\mathrm{pH}$ of 8.2 [based on Figure 5 in Lauber et al. (2009)]. Bacteroidetes is known to be important for the degradation of complex organic matter in marine environments, i.e., high molecular weight compounds, such as proteins and polysaccharides (Rosselló-Mora et al., 1999; Thomas et al., 2011). On the other hand, low $\mathrm{pH}$ conditions have been shown to benefit sulfate reducers, such as Desulfovibrio spp., in seagrass rhizospheres (Nielsen et al., 1999). In laboratory assays some sulfate reducers have the capacity to degrade recalcitrant organic matter (e.g., lignin; Goldfarb et al., 2011), however, isolates of Desulfovibrio from coastal sediments utilized primarily organic acids and some sugars (Nielsen et al., 1999). We therefore suggest that local sediment acidification can be an important driver of microbial community structure and function in vegetated coastal sediments, and thereby may also influence organic matter cycling within the sediments. However, such $\mathrm{pH}$-induced effects on the microbial community composition in the sediments were beyond the scope of this paper and need to be further investigated.

\section{$\mathrm{O}_{2}$ Consumption and Estimated Sulfate Reduction}

The higher $\mathrm{O}_{2}$ consumption rates and estimated sulfate reduction rates in the mangrove and seagrass surface sediments as compared to salt marsh surface sediments, indicates higher overall microbial activity (maybe as a result of higher labile carbon availability), and thus results in a shallower oxidized sediment zone. The diffusive $\mathrm{O}_{2}$ uptake and volume-specific $\mathrm{O}_{2}$ consumption rates of the seagrass surface sediments (for direct comparison, $R=256 \mu \mathrm{mol} \mathrm{m} \mathrm{m}^{-3} \mathrm{~s}^{-1}$ ) were similar to $\mathrm{O}_{2}$ consumption rates previously measured in seagrass meadows from the same region (Brodersen et al., 2017a). Estimated sulfate reduction rates and $\mathrm{O}_{2}$ consumption were also higher in surface sediment than deeper sediment layers for both seagrass and mangrove ecosystems, indicating higher organic matter content in the surface sediments, which aligns with previous results (Saintilan et al., 2013). No significant sulfate reduction was found in salt marsh sediment, which suggests low overall microbial activity. However, salt marsh ecosystems have been generally reported to have high sulfate reduction rates (e.g., Howarth and Teal, 1979). We hypothesize that the low microbial activity, and the deviation to previous findings, could be due to a few causes. First, a higher fraction of recalcitrant or stable carbon could be deposited in the salt marsh sediments that we sampled compared to the other habitats, which could have reduced the ability of the microbial communities to utilize the sediment carbon (Unger et al., 2016; Leorri et al., 2018). Second, there could have been high precipitation rates of FeS below the oxic sediment zone (Thamdrup et al., 1994) that prevented $\mathrm{H}_{2} \mathrm{~S}$ from accumulating in the sediment porewater. However, low $\mathrm{H}_{2} \mathrm{~S}$ accumulation rates do not necessarily indicate lower sulfate reduction rates in the sediment. The precipitation of FeS is driven by $\mathrm{H}_{2} \mathrm{~S}$ produced by sulfate reducers and the availability of $\mathrm{Fe}$ in the sediment, which is beyond what can be detected by the microsensor measurements in this study. Additionally, the low anaerobic metabolic rates in the salt marsh sediment could be due to their position in the upper intertidal zone, whereby the sediment surface is frequently exposed to air during low tide (i.e., molecular diffusion of $\mathrm{O}_{2}$ is 10,000 -fold faster in air as compared to water and $1 \mathrm{~L}$ of air holds 30 -fold more $\mathrm{O}_{2}$ than $1 \mathrm{~L}$ of water; Armstrong, 1979). The resulting large fluctuations in porewater salinity, temperature and $\mathrm{O}_{2}$ penetration depth in the sediment are, in turn, likely to affect microbial metabolism. 
Lastly, the sulfate reducers may be inhabiting sediment layers below the maximum microsensor profiling depth (i.e., down to $\sim 2 \mathrm{~cm}$ depth) used in this study and thus may not have been detected.

\section{Potential Influence of Physical Disturbance on VCH Carbon Sequestration}

High carbon accumulation rates due to particle trapping coupled with low to no occurrence of aerobic remineralization beyond the top $\mathrm{mm}$ of the sediment surface or the few $\mathrm{mm}$ surrounding the root tips (Pedersen et al., 1998; Frederiksen and Glud, 2006; Brodersen et al., 2014), supports the sequestration and preservation of sediment organic carbon. However, VCHs can be physically disturbed (e.g., boating activity, conversion, bioturbation by invertebrates) that would introduce $\mathrm{O}_{2}$ to previously anoxic layers (e.g., Macreadie et al., 2015). Exposing deep sediments to the surface provided insight into how disturbances and subsequence exposure to $\mathrm{O}_{2}$ could affect carbon stocks (Macreadie et al., 2017). Oxygen uptake of the deeper sediments indicated the activation of aerobes or facultative anaerobes present in the previously anoxic layers and/or transport and dispersal of facultative (or obligate) aerobes via the water column to the now exposed deeper sediment layers. Both aerobic and anaerobic metabolism in mangrove and seagrass sediments was generally lower for the deep sediments compared to surface sediments, suggesting either lower carbon substrate availability (Burdige, 2007) or lower enzyme utilization or efficiency (Arnosti, 2011). Regardless, $\mathrm{O}_{2}$ exposure did elicit aerobic microbial metabolism, a response that may represent a significant risk to carbon that has accumulated on decadal to millennial timescales.

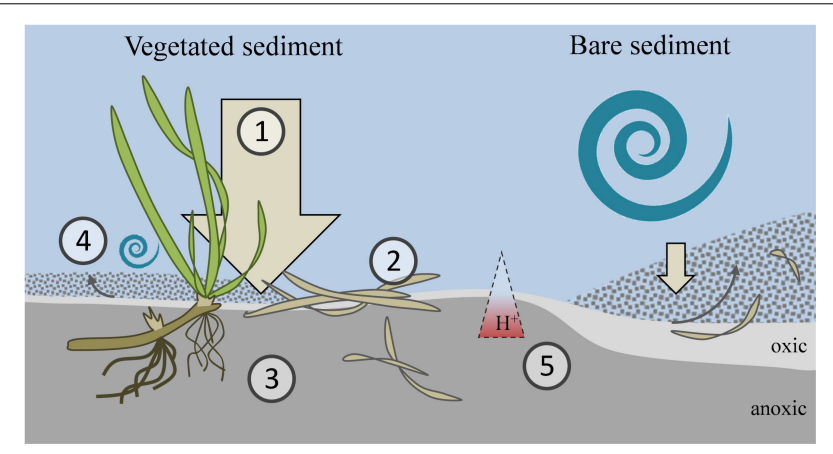

FIGURE 5 | Conceptual diagram of key factors influencing organic carbon sequestration in VCHs. (1) High sedimentation rate due to presence of plants capturing particles from the water column, increases burial of surface applied organic matter. (2) High input of organic material increases microbial activity at the sediment surface, ensuring low $\mathrm{O}_{2}$ penetration. (3) High carbon accumulation in deep, anoxic sediment (cm-m). (4) Low resuspension of sediment due to reduced flow across sediment. (5) Sediment acidification with depth potentially leading to inhibition of bacterial growth. Hence, VCHs, such as mangrove forests, salt marshes and seagrass meadows, are characterized by three important environmental properties: (i) high organic loading, (ii) high carbon burial rate, and (iii) efficient protection of the buried carbon, as opposed to unvegetated sediment.
Our study used $>50 \mathrm{~cm}$ carbon stock (i.e., a sediment core from $>50 \mathrm{~cm}$ depth) and likely represents extreme case of disturbance, e.g., dredging and shrimp aquaculture. However, with the frequency of natural (bioturbation) and anthropogenic (habitat clearing, boating scars) physical disturbances in VCHs (Teal et al., 2008; Pendleton et al., 2012), these results highlight the potential risk of increased vulnerability for carbon stock losses via microbial remineralization as a result of $\mathrm{O}_{2}$ exposure.

\section{CONCLUSION}

Our results showed that in the absence of biological $\mathrm{O}_{2}$ introduction mangrove and seagrass surface sediments had higher rates of $\mathrm{O}_{2}$ consumption and estimated sulfate reduction than salt marsh surface sediments in the Sydney area (NSW, Australia), with highest rates measured in the sediment surface of mangroves. We also found that surface of mangrove and seagrass sediments had higher $\mathrm{O}_{2}$ consumption and estimated sulfate reduction rates than deeper sediments, which is indicative of higher microbial activity and higher carbon resources. In addition, depth microprofiles of $\mathrm{pH}$ and $\mathrm{O}_{2}$ revealed pronounced sediment acidification with depth and low $\mathrm{O}_{2}$ penetration in all $\mathrm{VCH}$ sediments. The highest percent organic carbon content was found in sediments originating from mangrove forests, which also exhibited lowest $\mathrm{O}_{2}$ penetration depths and strongest sediment acidification with depth. The results from this case study suggests that the efficiency of the VCHs that we studied to store and bury carbon may in part be explained by $(i)$ the prevailing anoxic conditions in the bulk sediment in concert with (ii) rapid sediment acidification with depth. Both of these conditions have the potential to favor slower anaerobic microbial remineralization processes, thus adding to other important factors (e.g., high organic matter accumulation and low sediment resuspension) that influence organic carbon accumulation in VCHs (Figure 5). Conversely in scenarios of exposure of deep sediments to the surface (e.g., as a result of a dredging and/or dragging events), the subsequence exposure to $\mathrm{O}_{2}$ and likely activation of aerobic metabolism is hypothesized to be a mechanism for reducing carbon stocks in VCHs. Future research should thus be aiming at providing supporting evidence for many of the arguments made here, such as DIC measurements and the sources and quality of organic carbon, as well as determination of the iron content and/or iron speciation of the sediments (e.g., iron oxides, pyrite and $\mathrm{FeS}$ ), as these geochemical variables can affect the calculations of the microbial activity determined from the detailed microsensor measurements (i.e., Belshe et al., 2017).

\section{AUTHOR CONTRIBUTIONS}

$\mathrm{PM}, \mathrm{TA}, \mathrm{DN}, \mathrm{KEB}, \mathrm{RC}$, and $\mathrm{CL}$ designed the research. KEB (mangrove), ST-T (salt marsh), and DN (seagrass) conducted the experiments. KEB, ST-T, DN, TA, and PM processed and analyzed the data. KEB, ST-T, DN, TA, and PM wrote the 
manuscript with editorial help from all co-authors. All authors have given approval to the final version of the manuscript.

\section{FUNDING}

This project was supported by the CSIRO Flagship Marine and Coastal Carbon Biogeochemical Cluster and the Ocean and Atmosphere Flagship (PM and RC), as well as, by grants from the Augustinus Foundation (microsensor equipment and sensors,

\section{REFERENCES}

Alongi, D. M. (2002). Present state and future of the world's mangrove forests. Environ. Conserv. 29, 331-349. doi: 10.1017/S0376892902000231

Alongi, D. M. (2005). “Mangrove-microbe-soil relations," in Interactions Between Macro- and Microorganisms in Marine Sediments, eds E. Kristensen, R. R. Haese, and J. E. Kostka (Washington, DC: American Geophysical Union), 85-103. doi: 10.1029/CE060p0085

Armstrong, W. (1979). Aeration in Higher Plants. In Advances in Botanical Research, Vol. 7. London: Academic Press, London, 225-332.

Arnosti, C. (2011). Microbial extracellular enzymes and the marine carbon cycle. Ann. Rev. Mar. Sci. 3, 401-425. doi: 10.1146/annurev-marine-120709-142731

Atwood, T. B., Connolly, R. M., Almahasheer, H., Carnell, P. E., Duarte, C. M., Ewers Lewis, C. J., et al. (2017). Global patterns in mangrove soil carbon stocks and losses. Nat. Clim. Change 7, 523-528. doi: 10.1038/nclimate3326

Barbier, E. B., Hacker, S. D., Kennedy, C., Koch, E. W., Stier, A. C., and Silliman, B. R. (2011). The value of estuarine and coastal ecosystem services. Ecol. Monogr. 81, 169-193. doi: 10.1890/10-1510.1

Belshe, E. F., Mateo, M. A., Gillis, L., Zimmer, M., and Teichberg, M. (2017). Muddy waters: unintentional consequences of blue carbon research obscure our understanding of organic carbon dynamics in seagrass ecosystems. Front. Mar. Sci. 4:125. doi: 10.3389/fmars.2017.00125

Benner, R., Maccubbin, A. E., and Hodson, R. E. (1984). Anaerobic biodegradation of the lignin and polysaccharide components of lignocellulose and synthetic lignin by sediment microflora. Appl. Environ. Microbiol. 47, 998-1004.

Blaabjerg, V., and Finster, K. (1998). Sulphate reduction associated with roots and rhizomes of the marine macrophyte Zostera marina. Aquat. Microb. Ecol. 15, 311-314. doi: 10.3354/ame015311

Blaabjerg, V., Mouritsen, K. N., and Finster, K. (1998). Diel cycles of sulphate reduction rates in sediments of a Zostera marina bed (Denmark). Aquat. Microb. Ecol. 15, 97-102. doi: 10.3354/ame015097

Boll, M., Fuchs, G., and Heider, J. (2002). Anaerobic oxidation of aromatic compounds and hydrocarbons. Curr. Opin. Chem. Biol. 6, 604-611. doi: 10. 1016/S1367-5931(02)00375-7

Borum, J., Pedersen, O., Greve, T. M., Frankovich, T. A., Zieman, J. C., Fourqurean, J. W., et al. (2005). The potential role of plant oxygen and sulphide dynamics in die-off events of the tropical seagrass, Thalassia testudinum. J. Ecol. 93, 148-158. doi: 10.1111/j.1365-2745.2004.00943.x

Bourque, A. S., Kenworthy, W. J., and Fourqurean, J. W. (2015). Impacts of physical disturbance on ecosystem structure in subtropical seagrass meadows. Mar. Ecol. Prog. Ser. 540, 27-41. doi: 10.3354/meps11505

Brodersen, K. E., Hammer, K. J., Schrameyer, V., Floytrup, A., Rasheed, M. A., Ralph, P. J., et al. (2017a). Sediment resuspension and deposition on seagrass leaves impedes internal plant aeration and promotes phytotoxic H2S intrusion. Front. Plant Sci. 8:657. doi: 10.3389/fpls.2017.00657

Brodersen, K. E., Koren, K., Moßhammer, M., Ralph, P. J., Kühl, M., and Santner, J. (2017b). Seagrass-mediated phosphorus and iron solubilization in tropical sediments. Environ. Sci. Technol. 51, 14155-14163. doi: 10.1021/acs.est.7b03878

Brodersen, K. E., Koren, K., Lichtenberg, M., and Kühl, M. (2016). Nanoparticlebased measurements of $\mathrm{pH}$ and $\mathrm{O}_{2}$ dynamics in the rhizosphere of Zostera marina L.: effects of temperature elevation and light/dark transitions. Plant Cell Environ. 39, 1619-1630. doi: 10.1111/pce.12740

Brodersen, K. E., Nielsen, D. A., Ralph, P. J., and Kühl, M. (2014). A split flow chamber with artificial sediment to examine the below-ground
KEB) and the Carlsberg Foundation (Postdoctoral fellowship, CF16-0899, KEB).

\section{ACKNOWLEDGMENTS}

PM acknowledges the support of an Australian Research Council (ARC) Discovery Early Career Researcher Award (DE130101084) and an Australian Research Council (ARC) Linkage Grant (LP160100242).

microenvironment of aquatic macrophytes. Mar. Biol. 161, 2921-2930. doi: 10.1007/s00227-014-2542-3

Brodersen, K. E., Lichtenberg, M., Paz, L.-C., and Kühl, M. (2015a). Epiphyte-cover on seagrass (Zostera marina L.) leaves impedes plant performance and radial $\mathrm{O}_{2}$ loss from the below-ground tissue. Front. Mar. Sci. 2:58. doi: 10.3389/fmars. 2015.00058

Brodersen, K. E., Nielsen, D. A., Ralph, P. J., and Kühl, M. (2015b). Oxic microshield and local $\mathrm{pH}$ enhancement protects Zostera muelleri from sediment derived hydrogen sulphide. New Phytol. 205, 1264-1276. doi: 10.1111/nph. 13124

Burdige, D. J. (2005). Burial of terrestrial organic matter in marine sediments: a reassessment. Glob. Biogeochem. Cycles 19:GB4011. doi: 10.1029/2004GB002368

Burdige, D. J. (2007). Preservation of organic matter in marine sediments: controls, mechanisms, and an imbalance in sediment organic carbon budgets? Chem. Rev. 107, 467-485. doi: 10.1021/cr050347q

Burdige, D. J. (2011). Estuarine and coastal sediments - coupled biogeochemical cycling. Treatise Estuar. Coast. Sci. 5, 279-316. doi: 10.1016/B978-0-12-3747112.00511-8

Campbell, J. E., Lacey, E. A., Decker, R. A., Crooks, S., and Fourqurean, J. W. (2014). Carbon storage in seagrass beds of Abu Dhabi, United Arab emirates. Estuar. Coast. 38, 242-251. doi: 10.1007/s12237-014-9802-9

Canfield, D. E., Jørgensen, B. B., Fossing, H., Glud, R., Gundersen, J., Ramsing, N. B., et al. (1993). Pathways of organic carbon oxidation in three continental margin sediments. Mar. Geol. 113, 27-40. doi: 10.1016/0025-3227(93)90147-N

Collier, L., and Mackenzie, T. (2008). Brisbane Water Estuary Processes Study. Report Prepared for Gosford City Council and Department of Environment and Climate Change. Gordon: Cardno Lawson Treloar Pty Ltd, 50.

Colmer, T. D., Pedersen, O., Wetson, A. M., and Flowers, T. J. (2013). Oxygen dynamics in a salt-marsh soil and in Suaeda maritima during tidal submergence. Environ. Exp. Bot. 92, 73-82. doi: 10.1016/j.envexpbot.2012.07. 002

Costa, A. L., Carolino, M., and Caçador, I. (2007). Microbial activity profiles in Tagus estuary salt marsh sediments. Hydrobiologia 587, 169-175. doi: 10.1007/ s10750-007-0676-8

Costanza, R., d’Arge, R., de Groot, R., Farber, S., Grasso, M., and Hannon, B. (1997). The value of the world's ecosystem services and natural capital. Nature 387, 253-260. doi: 10.1038/387253a0

Cúcio, C., Engelen, A. H., Costa, R., and Muyzer, G. (2016). Rhizosphere microbiomes of European seagrasses are selected by the plant, but are not species specific. Front. Microbiol. 7:440. doi: 10.3389/fmicb.2016.00440

Duarte, C. M., Middelburg, J., and Caraco, N. (2005). Major role of marine vegetation on the oceanic carbon cycle. Biogeosciences 2, 1-8. doi: 10.1371/ journal.pone.0052932

Evans, W. C. (1977). Biochemistry of bacterial catabolism of aromatic-compounds in anaerobic environments. Nature 270, 17-22. doi: 10.1038/270017a0

Fenchel, T., King, G. M., and Blackburn, T. H. (1998). Bacterial Biogeochemistry: The Ecophysiology of Mineral Cycling. San Diego, CA: Academic Press, 1-27.

Fonseca, M. S., and Cahalan, J. A. (1992). A preliminary evaluation of wave attenuation by four species of seagrass. Estuar. Coast. Shelf Sci. 35, 565-576. doi: 10.1016/S0272-7714(05)80039-3

Fonseca, M. S., Thayer, G. W., Chester, A. J., and Foltz, C. (1984). Impact of scallop harvesting on eelgrass (Zostera marina) meadows: implications for management. N. Am. J. Fish. Manag. 4, 286-293. doi: 10.1577/1548-8659(1984) $4<286$ :IOSHOE $>2.0 . \mathrm{CO} ; 2$ 
Fourqurean, J. W., Duarte, C. M., Kennedy, H., Marbà, N., Holmer, H., Angel Mateo, M., et al. (2012). Seagrass ecosystems as a globally significant carbon stock. Nat. Geosci. 5, 505-509. doi: 10.1002/eap.1489

Frederiksen, M. S., and Glud, R. N. (2006). Oxygen dynamics in the rhizosphere of Zostera marina: a two-dimensional planar optode study. Limnol. Oceanogr. 51, 1072-1083. doi: 10.4319/lo.2006.51.2.1072

Geoscience Australia (2015). Australian Online Coastal Information - Ozcoasts. Available at: www.ozcoasts.gov.au

Goldfarb, K. C., Karaoz, U., Hanson, C. A., Santee, C. A., Bradford, M. A., Treseder, K. K., et al. (2011). Differential growth responses of soil bacterial taxa to carbon substrates of varying chemical recalcitrance. Front. Microbiol. 2:94. doi: $10.3389 /$ fmicb.2011.00094

Hansen, J. W., Udy, J. W., Perry, C. J., Dennison, W. C., and Lomstein, B. A. (2000). Effect of the seagrass Zostera capricorni on sediment microbial processes. Mar. Ecol. Prog. Ser. 199, 83-96. doi: 10.3354/meps 199083

Harborne, A. R., Mumby, P. J., Micheli, F., Perry, C. T., Dahlgren, C. P., Holmes, K. E., et al. (2006). The functional value of Caribbean coral reef, seagrass and mangrove habitats to ecosystem processes. Adv. Mar. Biol. 50, 57-189. doi: 10.1016/S0065-2881(05)50002-6

Hartnett, H. E., Keil, R. G., Hedges, J. I., and Devol, A. H. (1998). Influence of oxygen exposure time on organic carbon preservation in continental margin sediments. Nature 391, 572-574. doi: 10.1038/35351

Heider, J., and Fuchs, G. (1997). Anaerobic metabolism of aromatic compounds. Eur. J. Biochem. 243, 577-596. doi: 10.1111/j.1432-1033.1997.00577.x

Holmer, M., and Laursen, L. (2002). Effect of shading of Zostera marina (eelgrass) on sulfur cycling in sediments with contrasting organic matter and sulfide pools. J. Exp. Mar. Biol. Ecol. 270, 25-37. doi: 10.1016/S0022-0981(02) 00015-1

Howarth, R. W., and Giblin, A. (1983). Sulfate reduction in the salt marshes at Sapelo Island, Georgia 1. Limnol. Oceanogr. 28, 70-82. doi: 10.4319/lo.1983.28. 1.0070

Howarth, R. W., and Teal, J. M. (1979). Sulfate reduction in a New England salt marsh. Limnol. Oceanogr. 24, 999-1013. doi: 10.4319/lo.1979.24.6.0999

Isaksen, M. F., and Finster, K. (1996). Sulphate reduction in the root zone of the seagrass Zostera noltii on the intertidal flats of a coastal lagoon (Arcachon, France). Mar. Ecol. Prog. Ser. 137, 187-194. doi: 10.3354/meps137187

Jensen, S. I., Kühl, M., and Prieme, A. (2007). Different bacterial communities in the rhizoplane and bulk sediment of the seagrass Zostera marina. FEMS Microbiol. Ecol. 62, 108-117. doi: 10.1111/j.1574-6941.2007.00373.x

Jeroschewski, P., Steuckart, C., and Kühl, M. (1996). An amperometric microsensor for the determination of $\mathrm{H} 2 \mathrm{~S}$ in aquatic environments. Anal. Chem. 68, 4351-4357. doi: 10.1021/ac960091b

Johnson, C. R., Koch, M. S., Pedersen, O., and Madden, C. J. (2018). Hypersalinity as a trigger of seagrass (Thalassia testudinum) die-off events in Florida Bay: evidence based on shoot meristem $\mathrm{O}_{2}$ and $\mathrm{H} 2 \mathrm{~S}$ dynamics. J. Exp. Mar. Biol. Ecol. 504, 47-52. doi: 10.1016/j.jembe.2018.03.007

Jørgensen, B. B. (1982). Mineralization of organic matter in the sea bed-the role of sulphate reduction. Nature 296, 643-645. doi: 10.1038/296643a0

Jørgensen, B. B., and Revsbech, N. P. (1985). Diffusive boundary layers and the oxygen uptake of sediments and detritus. Limnol. Oceanogr. 30, 111-122. doi: 10.4319/lo.1985.30.1.0111

Koch, M. S., Mendelssohn, I. A., and McKee, K. L. (1990). Mechanism for the hydrogen sulfide-induced growth limitation in wetland macrophytes. Limnol. Oceanogr. 35, 399-408. doi: 10.4319/lo.1990.35.2.0399

Koop-Jakobsen, K., Fischer, J., and Wenzhöfer, F. (2017). Survey of sediment oxygenation in rhizospheres of the saltmarsh grass - Spartina anglica. Sci. Total Environ. 589, 191-199. doi: 10.1016/j.scitotenv.2017.02.147

Koop-Jakobsen, K., Mueller, P., Meier, R. J., Liebsch, G., and Jensen, K. (2018). Plant-sediment interactions in salt marshes-an optode imaging study of $\mathrm{O}_{2}$, $\mathrm{pH}$, and $\mathrm{CO}_{2}$ gradients in the rhizosphere. Front. Plant Sci. 9:541. doi: 10.3389/ fpls.2018.00541

Koren, K., Brodersen, K. E., Jakobsen, S. L., and Kühl, M. (2015). Optical sensor nanoparticles in artificial sediments - a new tool to visualize $\mathrm{O}_{2}$ dynamics around the rhizome and roots of seagrasses. Environ. Sci. Technol. 49, 2286-2292. doi: 10.1021/es505734b

Kristensen, E., Bouillon, S., Dittmar, T., and Marchand, C. (2008). Organic carbon dynamics in mangrove ecosystems: a review. Aquat. Bot. 89, 201-219. doi: 10.1016/j.aquabot.2007.12.005
Kühl, M., and Jørgensen, B. B. (1992). Microsensor measurements of sulfate reduction and sulfide oxidation in compact microbial communities of aerobic biofilms. Appl. Environ. Microbiol. 58, 1164-1174.

Kühl, M., and Revsbech, N. P. (2001). "Biogeochemical microsensors for boundary layer studies," in The Benthic Boundary Layer, eds B. P. Boudreau and B. B. Jørgensen (New York, NY: Oxford University Press), 180-210.

Kühl, M., Steuckart, C., Eickert, G., and Jeroschewski, P. (1998). A H2S microsensor for profiling sediments and biofilms: application in acidic sediment. Aquat. Microb. Ecol. 15, 201-209. doi: 10.3354/ame015201

Lamers, L. P., Govers, L. L., Janssen, I. C., Geurts, J. J., Van der Welle, M. E., Van Katwijk, M. M., et al. (2013). Sulfide as a soil phytotoxin-a review. Front. Plant Sci. 4:268. doi: 10.3389/fpls.2013.00268

Lauber, C. L., Hamady, M., Knight, R., and Fierer, N. (2009). Pyrosequencing-based assessment of soil $\mathrm{pH}$ as a predictor of soil bacterial community structure at the continental scale. Appl. Environ. Microbiol. 75, 5111-5120. doi: 10.1128/AEM. 00335-09

Leorri, E., Zimmerman, A. R., Mitra, S., Christian, R. R., Fatela, F., and Mallinson, D. J. (2018). Refractory organic matter in coastal salt marshes-effect on C sequestration calculations. Sci. Total Environ. 633, 391-398. doi: 10.1016/j. scitotenv.2018.03.120

Long, M. H., McGlathery, K. J., Zieman, J. C., and Berg, P. (2008). The role of organic acid exudates in liberating phosphorus from seagrass-vegetated carbonate sediments. Limnol. Oceanogr. 53, 2616-2626. doi: 10.4319/lo.2008. 53.6.2616

Lovell, C. R. (2005). "Belowground interactions among salt marsh plants and microorganisms," in Interactions Between Macro- and Microorganisms in Marine Sediments, eds E. Kristensen, R. R. Haese, and J. E. Kostka (Washington, DC: American Geophysical Union), 61-83. doi: 10.1029/CE060p0061

Lovelock, C. E., Fourqurean, J. W., and Morris, J. T. (2017). Modeled $\mathrm{CO}_{2}$ emissions from coastal wetland transitions to other land uses: tidal marshes, mangrove forests, and seagrass beds. Front. Mar. Sci. 4:143. doi: 10.3389/fmars. 2017.00143

Macreadie, P. I., Ewers-Lewis, C. J., Whitt, A. A., Ollivier, Q., Stacey, M., Carnell, P., et al. (2015). Losses and recovery of organic carbon from a seagrass ecosystem following disturbance. Proc. R. Soc. B Biol. Sci. 282, 1-6. doi: 10.1098/rspb.2015. 1537

Macreadie, P. I., Nielsen, D. A., Kelleway, J. J., Atwood, T. B., Seymour, J. R., Petrou, K., et al. (2017). Can we manage coastal ecosystems to sequester more blue carbon? Front. Ecol. Environ. 15, 206-213. doi: 10.1002/fee. 1484

McLeod, E., Chmura, G. L., Bouillon, S., Salm, R., Björk, M., Duarte, C. M., et al. (2011). A blueprint for blue carbon: toward an improved understanding of the role of vegetated coastal habitats in sequestering $\mathrm{CO}_{2}$. Front. Ecol. Environ. 9, 552-560. doi: 10.1890/110004

Miyajima, T., Koike, I., Yamano, H., and Iizumi, H. (1998). Accumulation and transport of seagrass-derived organic matter in reef flat sediment of Green Island, Great Barrier Reef. Mar. Ecol. Prog. Ser. 175, 251-259. doi: 10.3354/ meps175251

Moriarty, D. J. W., Iverson, R. L., and Pollard, P. C. (1986). Exudation of organic carbon by the seagrass Halodule wrightii Aschers. And its effect on bacterial growth in the sediment. J. Exp. Mar. Biol. Ecol. 96, 115-126. doi: 10.1016/00220981(86)90237-6

Neckles, H. A., Short, F. T., Barker, S., and Kopp, B. S. (2005). Disturbance of eelgrass Zostera marina by commercial mussel Mytilus edulis harvesting in Maine: dragging impacts and habitat recovery. Mar. Ecol. Prog. Ser. 285, 57-73. doi: $10.3354 /$ meps 285057

Nielsen, A. H., Vollertsen, J., and Hvitved-Jacobsen, T. (2006). Kinetics and stoichiometry of aerobic sulfide oxidation in wastewater from sewers - effects of $\mathrm{pH}$ and temperature. Water Environ. Res. 78, 275-283. doi: 10.2175/ 106143005X94367

Nielsen, J. T., Liesack, W., and Finster, K. (1999). Desulfovibrio zosterae sp. nov., a new sulfate reducer isolated from surface-sterilized roots of the seagrass Zostera marina. Int. J. Syst. Evol. Microbiol. 49, 859-865. doi: 10.1099/00207713-4 9-2-859

Nielsen, L. B., Finster, K., Welsh, D. T., Donelly, A., Herbert, R. A., De Wit, R., et al. (2001). Sulphate reduction and nitrogen fixation rates associated with roots, rhizomes and sediments from Zostera noltii and Spartina maritima meadows. Environ. Microbiol. 3, 63-71. doi: 10.1046/j.1462-2920.2001.00160.x 
Pagès, A., Teasdale, P. R., Robertson, D., Bennett, W. W., Schäfer, J., and Welsh, D. T. (2011). Representative measurement of two-dimensional reactive phosphate distributions and co-distributed iron(II) and sulfide in seagrass sediment porewaters. Chemosphere 85, 1256-1261. doi: 10.1016/j.chemosphere. 2011.07.020

Pedersen, O., Binzer, T., and Borum, J. (2004). Sulphide intrusion in eelgrass (Zostera marina L.). Plant Cell Environ. 27, 595-602. doi: 10.1111/j.1365-3040. 2004.01173.x

Pedersen, O., Borum, J., Duarte, C. M., and Fortes, M. D. (1998). Oxygen dynamics in the rhizosphere of Cymodocea rotundata. Mar. Ecol. Prog. Ser. 169, 283-288. doi: 10.3354/meps169283

Pendleton, L., Donato, D. C., Murray, B. C., Crooks, S., Jenkins, W. A., Sifleet, S., et al. (2012). Estimating global "blue carbon" emissions from conversion and degradation of vegetated coastal ecosystems. PLoS One 7:e43542. doi: 10.1371/ journal.pone.0043542

Peterson, C. H., Summerson, H. C., and Fegley, S. R. (1988). Ecological consequences of mechanical harvesting of clams. Fish. Bull. 85, 281-298.

Pollard, P. C., and Moriarty, D. J. W. (1991). Organic carbon decomposition, primary and bacterial productivity, and sulphate reduction, in tropical seagrass beds of the Gulf of Carpentaria, Australia. Mar. Ecol. Prog. Ser. 69, 149-159. doi: 10.3354/meps069149

Ramsing, N., and Gundersen, J. (1994). Seawater and Gases-Tabulated Physical Parameters of Interest to People Working with Microsensors in Marine Systems. Available at: www.unisense.com

Rasmussen, H., and Jørgensen, B. B. (1992). Microelectrode studies of seasonal oxygen uptake in a coastal sediment: role of molecular diffusion. Mar. Ecol. Prog. Ser. 81, 289-303. doi: 10.3354/meps081289

Revsbech, N. P. (1989). An oxygen microsensor with a guard cathode. Limnol. Oceanogr. 34, 474-478. doi: 10.4319/lo.1989.34.2.0474

Ricart, A. M., York, P. H., Rasheed, M. A., Perez, M., Romero, J., Bryant, C. V., et al. (2015). Variability of sedimentary organic carbon in patchy seagrass landscapes. Mar. Pollut. Bull. 100, 476-482. doi: 10.1016/j.marpolbul.2015. 09.032

Rosselló-Mora, R., Thamdrup, B., Schäfer, H., Weller, R., and Amann, R. (1999). The response of the microbial community of marine sediments to organic carbon input under anaerobic conditions. Syst. Appl. Microbiol. 22, 237-248. doi: 10.1016/S0723-2020(99)80071-X

Saintilan, N., Rogers, K., Mazumder, D., and Woodroffe, C. (2013). Allochthonous and autochthonous contributions to carbon accumulation and carbon store in southeastern Australian coastal wetlands. Estuar. Coast. Shelf Sci. 128, 84-92. doi: 10.1016/j.ecss.2013.05.010

Schrameyer, V., York, P. H., Chartrand, K., Ralph, P. J., Kühl, M., Brodersen, K. E., et al. (2018). Contrasting impacts of light reduction on sediment biogeochemistry in deep- and shallow-water tropical seagrass assemblages (Green Island, Great Barrier Reef). Mar. Environ. Res. 136, 38-47. doi: 10.1016/ j.marenvres.2018.02.008

Soetaert, K., Hofmann, A. F., Middelburg, J. J., Meysman, F. J., and Greenwood, J. (2007). Reprint of “The effect of biogeochemical processes on $\mathrm{pH}$ ". Mar. Chem. 106, 380-401. doi: 10.1016/j.marchem.2007.06.008
Teal, L., Bulling, M. T., Parker, E., and Solan, M. (2008). Global patterns of bioturbation intensity and mixed depth of marine soft sediments. Aquat. Biol. 2, 207-218. doi: 10.3354/ab00052

Thamdrup, B., Fossing, H., and Jørgensen, B. B. (1994). Manganese, iron and sulfur cycling in a coastal marine sediment, Aarhus Bay, Denmark. Geochim. Cosmochim. Acta 58, 5115-5129. doi: 10.1016/0016-7037(94) 90298-4

Thomas, F., Hehemann, J.-H., Rebuffet, E., Czjzek, M., and Michel, G. (2011). Environmental and gut Bacteroidetes: the food connection. Front. Microbiol. 2:93. doi: $10.3389 /$ fmicb.2011.00093

Trevathan-Tackett, S. M., Seymour, J. R., Nielsen, D. A., Macreadie, P. I., Jeffries, T. C., Sanderman, J., et al. (2017). Sediment anoxia limits microbial-driven seagrass carbon remineralization under warming conditions. FEMS Microbiol. Ecol. 93:fix033. doi: 10.1093/femsec/fix033

Trevathan-Tackett, S. M., Thomson, A. C., Ralph, P. J., and Macreadie, P. I. (2018a). Fresh carbon inputs to seagrass sediments induce variable microbial priming responses. Sci. Total Environ. 621, 663-669. doi: 10.1016/j.scitotenv.2017. 11.193

Trevathan-Tackett, S. M., Wessel, C., Cebrián, J., Ralph, P. J., Masqué, P., and Macreadie, P. I. (2018b). Effects of small-scale, shading-induced seagrass loss on blue carbon storage: implications for management of degraded seagrass ecosystems. J. Appl. Ecol. 55, 1351-1359. doi: 10.1111/1365-2664.13081

Unger, V., Elsey-Quirk, T., Sommerfield, C., and Velinsky, D. (2016). Stability of organic carbon accumulating in Spartina alterniflora-dominated salt marshes of the Mid-Atlantic US. Estuar. Coast. Shelf Sci. 182, 179-189. doi: 10.1016/j. ecss.2016.10.001

Unsworth, R. K., and Cullen-Unsworth, L. C. (2017). Seagrass meadows. Curr. Biol. 27, R443-R445. doi: 10.1016/j.cub.2017.01.021

Unsworth, R. K., Williams, B., Jones, B. L., and Cullen-Unsworth, L. C. (2017). Rocking the boat: damage to eelgrass by swinging boat moorings. Front. Plant Sci. 8:1309. doi: 10.3389/fpls.2017.01309

Ward, L. G., Kemp, W. M., and Boynton, W. R. (1984). The influence of waves and seagrass communities on suspended particulates in an estuarine embayment. Mar. Geol. 59, 85-103. doi: 10.1016/0025-3227(84)90089-6

Welsh, D. T. (2000). Nitrogen fixation in seagrass meadows: regulation, plantbacteria interactions and significance to primary productivity. Ecol. Lett. 3, 58-71. doi: 10.1046/j.1461-0248.2000.00111.x

Conflict of Interest Statement: The authors declare that the research was conducted in the absence of any commercial or financial relationships that could be construed as a potential conflict of interest.

Copyright (c) 2019 Brodersen, Trevathan-Tackett, Nielsen, Connolly, Lovelock, Atwood and Macreadie. This is an open-access article distributed under the terms of the Creative Commons Attribution License (CC BY). The use, distribution or reproduction in other forums is permitted, provided the original author $(s)$ and the copyright owner(s) are credited and that the original publication in this journal is cited, in accordance with accepted academic practice. No use, distribution or reproduction is permitted which does not comply with these terms. 